\title{
Optimum Load Shedding in Power System Strategies with Voltage Stability Indicators
}

\author{
P. AJAY-D-VIMAL RAJ, M. SUDHAKARAN \\ Department of Electrical and Electronics Engineering, \\ Pondicherry Engineering College, Pondicherry, India \\ E-mail:ajayvimal@yahoo.com,karan_mahalingam@yahoo.com \\ Received August 20, 2009; revised September 23, 2009; accepted September 28, 2009
}

\begin{abstract}
An optimal load shedding strategy for power systems with optimum location and quantity of load to be shed is presented in this paper. The problem of load shedding for avoiding the existence of voltage instability in power systems is taken as a remedial action during emergency state in transmission and distribution sector.Optimum location of loads to be shed is found together with their optimum required quantity. L-Indicator index is in used for this purpose with a modified new technique. Applications to be standard 6 bus Ward-Hale test system and IEEE - 14 bus system are presented to validate the applicability of the proposed technique to any system of any size.
\end{abstract}

Keywords: Load Shedding, Voltage Instability, Power systems, Transmission and Distribution Power system

\section{Introduction}

The major objective of power systems is to supply electricity to its customers. During emergency state of the power system, it may shed partial loads to ensure the power supply to important loads, as the last resort to maintain system integrity. Load shedding in bulk power system has been studied many years [1-6].

In electric power systems heavy loading may lead to voltage instabilities or collapses or in the extreme to complete blackouts. One technique of avoiding voltage instability is to shed some consumer's loads in Order to draw the operating point for away from the critical voltage value.

Many techniques have been developed [7-13] to minimize the load curtailment without violating the system security constraints. The emergency state in the power System with distributed generations has been formulated the load shedding is solved as an optimization problem [14]. Ying Lu et al. [15] has proposed a load shedding scheme, working with various load models, such as single-motor model, two-motor model, and composite model. Armanda et al. [16] have adopted a Distributed Interruptible Load Shedding (DILS) program instead of the traditional methodologies based on the separation of some users and/or entire distribution feeders, according to programmed plans of emergency. Andrzej Wiszniewski [17] have formulated a new method for estimating the voltage stability margin, which utilizes local measurements and applied criterion is based on the very definition of the voltage stability. Zhiping Ding et al. [18] have developed an expert-system-based load shedding scheme (LSS) for ship power systems. Emmanuel J. Thalassinakis et al. [19] have built an efficient computational methodology that can be used for calculating the appropriate strategy for load shedding protection in autonomous power systems.

In this paper a fast method for determining the location and quantity of the load to be shed in order to avoid risk of voltage instability is presented. The method defines clearly the bus where load shedding should make. A relation between voltage stability indicator changes and load power to be shed is developed. Using the relation the amount of load to be shed is determined. An algorithm has been developed for determining the location and quality of load to be shed and tested with tbe standard 6 buses Ward-Hale test system and IEEE - 14 bus system. The proposed method is valid for any system of any size at any loading conditions.

\section{Mathematical Calculation for Load Shedding Using Voltage Stability Indicator- METHOD I}

From the indicator proposed in [3] voltage stability indi- 
cator at bus $\mathrm{j}$ can determine by

$$
B_{j}=\left|1-\frac{\sum_{i \in \alpha G} C_{j i} V_{i}}{V_{j}}\right| \quad j \in \alpha L
$$

where

$\alpha_{\mathrm{L}} \quad$ : Set of load buses.

$\alpha_{\mathrm{G}}$ : Set of generator buses.

$\mathrm{V}_{\mathrm{i}}$ : Voltage of generator bus $\mathrm{i}$.

$\mathrm{V}_{\mathrm{j}} \quad$ : Voltage of load bus $\mathrm{j}$.

$\mathrm{C}_{\mathrm{ji}}$ : Elements of matrix $\mathrm{C}$ determined by

$$
[\mathrm{C}]=-\left[\mathrm{B}_{\mathrm{LL}}\right]^{-1}\left[\mathrm{~B}_{\mathrm{LG}}\right]
$$

$\left[\mathrm{B}_{\mathrm{LL}}\right]^{-1}$ is the imaginary part of the matrix $\left[\mathrm{Y}_{\mathrm{LL}}\right]^{-1}$

$\left[\mathrm{B}_{\mathrm{LG}}\right]$ is the imaginary part of the matrix $\left[\mathrm{Y}_{\mathrm{LG}}\right]$

$\left[\mathrm{B}_{\mathrm{LL}}\right]^{-1}$ and $\left[\mathrm{B}_{\mathrm{LG}}\right]$ are susceptance matrices.

$\left[\mathrm{Y}_{\mathrm{LL}}\right]$ and $\left[\mathrm{Y}_{\mathrm{LG}}\right]$ are submatrices for the Y-Bus matrix.

The indicator at bus $\mathrm{j}$, determined by equation (1) can be separated into real and imaginary parts $\left(\mathrm{B}_{\mathrm{j}}^{\mathrm{R}}, \mathrm{B}_{\mathrm{j}}^{\mathrm{I}}\right)$ :

$$
\begin{gathered}
\mathrm{B}_{\mathrm{j}}=1-\frac{\sum_{\mathrm{i}=1}^{\alpha \mathrm{G}} \mathrm{C}_{\mathrm{ji}}\left|\mathrm{V}_{\mathrm{i}}\right| \mid \delta i}{\left|\mathrm{~V}_{\mathrm{j} \mid}\right| \delta j} \\
\mathrm{~B}_{\mathrm{j}}^{\mathrm{R}}+\mathrm{j} \mathrm{B}_{\mathrm{j}}^{\mathrm{I}}=1-\frac{\sum_{\mathrm{i}=1}^{\alpha \mathrm{G}} \mathrm{C}_{\mathrm{ji}}\left|\mathrm{V}_{\mathrm{i}}\right| \mid \delta \mathrm{i}-\delta \mathrm{j}}{\left|\mathrm{V}_{\mathrm{j}}\right|} \\
\mathrm{B}_{\mathrm{j}}^{\mathrm{R}}=1-\frac{\sum_{\mathrm{i}=1}^{\alpha \mathrm{G}} \mathrm{C}_{\mathrm{ji}}\left|\mathrm{V}_{\mathrm{i}}\right| \cos (\delta \mathrm{i}-\delta \mathrm{j})}{\left|\mathrm{V}_{\mathrm{j}}\right|} \\
\mathrm{B}_{\mathrm{j}}^{\mathrm{I}}=-\frac{\sum_{\mathrm{i}=1}^{\alpha \mathrm{G}} \mathrm{C}_{\mathrm{ji}}\left|\mathrm{V}_{\mathrm{i}}\right| \sin (\delta \mathrm{i}-\delta \mathrm{j})}{\left|\mathrm{V}_{\mathrm{j}}\right|}
\end{gathered}
$$

$\delta \mathrm{i}, \delta \mathrm{j}$ : voltage angles at buses $\mathrm{i}$ and $\mathrm{j}$

$\left|\mathrm{V}_{\mathrm{i}}\right|,\left|\mathrm{V}_{\mathrm{j}}\right|$ :voltage magnitudes at buses $\mathrm{i}$ and $\mathrm{j}$

The voltage stability indicator at each bus is a function of voltage angle and magnitude. The real imaginary part of indicator can be expressed as:

$$
\begin{aligned}
& \mathrm{B}^{\mathrm{I}}=\mathrm{F}_{1}(\delta,|\mathrm{V}|) \\
& \mathrm{B}^{\mathrm{R}}=\mathrm{F}_{2}(\delta,|\mathrm{V}|)
\end{aligned}
$$

The partial derivative of Equations (5) and (6) with respect to voltage angle and magnitude changes can be determined as:

$$
\left[\begin{array}{c}
\Delta \mathrm{B}^{\mathrm{I}} \\
\Delta \mathrm{B}^{\mathrm{R}}
\end{array}\right]=\left[\begin{array}{c}
\frac{\partial \mathrm{B}^{\mathrm{I}}}{\partial \delta} \frac{\partial \mathrm{B}^{\mathrm{I}}}{\partial|\mathrm{V}|} \\
\frac{\partial \mathrm{B}^{\mathrm{R}}}{\partial \delta} \frac{\partial \mathrm{B}^{\mathrm{R}}}{\partial|\mathrm{V}|}
\end{array}\right]\left[\begin{array}{l}
\Delta \delta \\
\Delta|\mathrm{V}|
\end{array}\right]=[\mathrm{T}]\left[\begin{array}{l}
\Delta \delta \\
\Delta|\mathrm{V}|
\end{array}\right]
$$

Matrix [T] is sensitivity matrix between indicator changes and voltage angle and magnitude changes

Coefficient of matrix [T] can be determined as

$$
\frac{\partial B_{J}^{I}}{\partial \delta i}=-\frac{C_{j i}\left|V_{i}\right| \cos (\delta i-\delta j)}{\left|V_{j}\right|} \quad i \in \alpha_{G}, i \neq s
$$

( $\mathrm{S}$ indicates the swing bus)

$$
\begin{gathered}
\frac{\partial B_{j}^{I}}{\partial \delta j}=\frac{\sum_{i \in \alpha G} C_{j i}\left|V_{i}\right| \cos (\delta i-\delta j)}{\left|V_{j}\right|}=-\left(B_{j}^{R}-1\right) f \\
\frac{\partial B_{j}^{R}}{\partial \delta i}=\frac{C_{j i}\left|V_{i}\right| \sin (\delta i-\delta j)}{\left|V_{j}\right|} \\
\frac{\partial B_{j}^{R}}{\partial \delta j}=-\frac{\sum_{i \in \alpha G} C_{j i}\left|V_{i}\right| \sin (\delta i-\delta j)}{\partial B_{j}^{I}}=B_{j}^{I} \\
\frac{\partial V_{j} \mid}{\sum_{i \in \alpha G} C_{j i}\left|V_{i}\right| \sin (\delta i-\delta j)}=-\frac{B_{j}^{I}}{\left|V_{j}\right|} \\
\frac{\partial B_{j}^{R}}{\partial\left|V_{j}\right|}=\frac{\sum_{i \in \alpha G} C_{j i}^{2}\left|V_{i}\right| \cos (\delta i-\delta j)}{\left|V_{j}\right|^{2}}=-\frac{B_{j}^{R}-1}{\left|V_{j}\right|}
\end{gathered}
$$

From conventional Newton-Raphson load flow we obtain a linear relation between changes in voltage phases/magnitudes and active/reactive power injections as:

$$
\left[\begin{array}{l}
\Delta \delta \\
\Delta|\mathrm{V}|
\end{array}\right]=[\mathrm{j}]^{-1}\left[\begin{array}{l}
\Delta \mathrm{P} \\
\Delta \mathrm{Q}
\end{array}\right]
$$

Sub (15) in (8) we get a relationship between real and imaginary part indicators and injected power as:

$$
\left[\begin{array}{c}
\Delta \mathrm{B}^{\mathrm{I}} \\
\Delta \mathrm{B}^{\mathrm{R}}
\end{array}\right]=[\mathrm{T}][\mathrm{j}]^{-1}\left[\begin{array}{c}
\Delta \mathrm{P} \\
\Delta \mathrm{Q}
\end{array}\right]
$$

A relationship between changes in indicators at load bus $\mathrm{j}$ and power injections at all load buses can be obtained:

$$
\begin{array}{r}
\Delta \mathrm{B}_{\mathrm{j}}^{\mathrm{I}}=\mathrm{S}_{11} \Delta \mathrm{P}_{\mathrm{j}}+\mathrm{S}_{12} \Delta \mathrm{Q}_{\mathrm{j}} \\
\Delta \mathrm{B}_{\mathrm{j}}^{\mathrm{R}}=\mathrm{S}_{21} \Delta \mathrm{P}_{\mathrm{j}}+\mathrm{S}_{22} \Delta \mathrm{Q}_{\mathrm{j}}
\end{array}
$$


The active and reactive loads are not independent; one cannot shed active load, without curtailing reactive loads. Usually, a relation between active and reactive load at bus $\mathrm{j}$ can be obtained as follows. Here the load power factor is assumed to be constant at each load bus.

$$
\begin{gathered}
P f_{j}=\frac{Q_{j}}{P_{j}} \quad j \in \alpha_{L} \\
P f_{j}=\frac{\Delta Q_{j}}{\Delta P_{j}} \\
\Delta Q_{j}=P_{j} \Delta P_{j}
\end{gathered}
$$

Sub (19) in (17and18) we get a relationship between changes of the indicator at bus $\mathrm{j}$ and changes in active power injected at the same bus can be obtained as

$$
\begin{gathered}
\Delta \mathrm{B}_{\mathrm{j}}^{\mathrm{I}=} \mathrm{S}_{11} \Delta \mathrm{P}_{\mathrm{j}}+\mathrm{S}_{12} \mathrm{Pf}_{\mathrm{j}} \Delta \mathrm{P}_{\mathrm{j}} \\
\Delta \mathrm{B}_{\mathrm{j}}^{\mathrm{R}}=\mathrm{S}_{21} \Delta \mathrm{P}_{\mathrm{j}}+\mathrm{S}_{22} \mathrm{Pf}_{\mathrm{j}} \Delta \mathrm{P}_{\mathrm{j}} \\
\Delta \mathrm{B}_{\mathrm{j}}^{\mathrm{I}}=\mathrm{S}_{1} \Delta \mathrm{P}_{\mathrm{j}} \\
\Delta \mathrm{B}_{\mathrm{j}}^{\mathrm{R}}=\mathrm{S}_{2} \Delta \mathrm{P}_{\mathrm{j}}
\end{gathered}
$$

where

$$
\begin{gathered}
\mathrm{S}_{1}=\mathrm{S}_{11}+\mathrm{S}_{12} \mathrm{Pf}_{\mathrm{j}} \\
\mathrm{S}_{2}=\mathrm{S}_{21}+\mathrm{S}_{22} \mathrm{Pf}_{\mathrm{j}}
\end{gathered}
$$

We know

$$
\begin{gathered}
\Delta \mathrm{B}_{\mathrm{j}}=\sqrt{\left(\Delta \mathrm{B}_{\mathrm{j}}^{\mathrm{I}}\right)^{2}+\left(\Delta \mathrm{B}_{\mathrm{j}}^{\mathrm{R}}\right)^{2}} \\
\Delta \mathrm{B}_{\mathrm{j}}=\sqrt{\mathrm{S}_{1}^{2} \Delta \mathrm{P}_{\mathrm{j}}^{2}+\mathrm{S}_{2}^{2} \Delta \mathrm{P}_{\mathrm{j}}^{2}} \\
\Delta \mathrm{B}_{\mathrm{j}}=\sqrt{\left(\mathrm{S}_{1}^{2}+\mathrm{S}_{2}^{2}\right) \Delta \mathrm{P}_{\mathrm{j}}^{2} s} \\
\Delta \mathrm{B}_{\mathrm{j}}=\Delta \mathrm{P}_{\mathrm{j}} \sqrt{\left(\mathrm{S}_{1}^{2}+\mathrm{S}_{2}^{2}\right)} \\
\Delta \mathrm{P}_{\mathrm{j}}=\frac{\Delta \mathrm{B}_{\mathrm{j}}}{\sqrt{\left(\mathrm{S}_{1}^{2}+\mathrm{S}_{2}{ }^{2}\right)}} \\
\Delta \mathrm{Q}_{\mathrm{j}}=\mathrm{Pf}_{\mathrm{j}} \Delta \mathrm{P}_{\mathrm{j}}
\end{gathered}
$$

Using Equation (28) reactive power to be shed at bus $\mathrm{j}$ can be obtained if the active power to be shed at bus $\mathrm{j}$ is known.

\section{Improved Method for Load Shedding By Voltage Stability Indicator}

There are several methods for improving the voltage conditions in a power system as suggested in various articles.
In the improved method, the voltage profile is enhanced by determining the location and quantity of load to be shed, such that voltage instability can be avoided.

This method is based on the indicators of risk of voltage instability suggested by $\mathrm{P}$. Kessel and H. Glavitsch [3]. The improved technique is a modification of the technique for previous section. It defines clearly the bus where the load shedding should be made. A relation between indicator changes and load powers to be shed is developed here. Using this relation, the amount of load to be shed is determined, for any operational situation.

\section{Mathematical Calculation for Load Shedding Using Improved Voltage Stability Indicator- METHOD II}

Kessel and Glavitsch [3] have developed a voltage stability indicator at load bus $\mathrm{j}$

$$
L_{j}=\left|1-\frac{\sum_{i \in \alpha G} F_{j i} V_{i}}{V_{j}}\right| \quad J \in \alpha L
$$

where

$\alpha_{\mathrm{L}} \quad$ : Set of load buses.

$\alpha_{\mathrm{G}} \quad$ : Set of generator buses.

$\mathrm{V}_{\mathrm{i}} \quad$ : Voltage of generator bus i.

$\mathrm{V}_{\mathrm{j}}$ : Voltage of load bus $\mathrm{j}$.

$$
\begin{aligned}
& {[\mathrm{Y}]=\left[\begin{array}{cc}
\mathrm{Y}_{\mathrm{GG}} & \mathrm{Y}_{\mathrm{GL}} \\
\mathrm{Y}_{\mathrm{LG}} & \mathrm{Y}_{\mathrm{LL}}
\end{array}\right]} \\
& {[\mathrm{F}]=-\left[\mathrm{Y}_{\mathrm{LL}}\right]^{-1}\left[\mathrm{Y}_{\mathrm{LG}}\right]}
\end{aligned}
$$

$\mathrm{Y}_{\mathrm{GG}}, \mathrm{Y}_{\mathrm{LL}}, \mathrm{Y}_{\mathrm{LG}}, \mathrm{Y}_{\mathrm{GL}}$ : Elements of system admittance matrix

A global voltage stability indicator of a power system is given by $\mathrm{L}, 0 \leq \mathrm{L} \leq 1$

0 : far away from voltage instability point.

1: at voltage instability point.

The indicator at bus j determined by Equation (29) can be separated into real and imaginary part $\left(\mathrm{L}_{\mathrm{j}}^{\mathrm{R}}, \mathrm{L}_{\mathrm{j}}^{\mathrm{I}}\right)$

$$
\mathrm{L}_{\mathrm{j}}^{\mathrm{R}}+\mathrm{jL} \mathrm{L}_{\mathrm{j}}^{\mathrm{I}}=1-\frac{\sum_{\mathrm{i} \in \mathrm{aG}}\left|\mathrm{F}_{\mathrm{ji}}\right|\left|\mathrm{V}_{\mathrm{i}}\right| \mid \theta_{\mathrm{ji}}+\delta_{\mathrm{i}}-\delta_{\mathrm{j}}}{\left|\mathrm{V}_{\mathrm{j}}\right|}
$$

$$
\mathrm{L}_{\mathrm{j}}^{\mathrm{R}}=1-\frac{\sum_{\mathrm{i} \in \alpha \mathrm{G}}\left|\mathrm{F}_{\mathrm{ji}}\right|\left|\mathrm{V}_{\mathrm{i}}\right| \cos \mid \theta_{\mathrm{ji}}+\delta_{\mathrm{i}}-\delta_{\mathrm{j}}}{\left|\mathrm{V}_{\mathrm{j}}\right|}
$$




$$
\mathrm{L}_{\mathrm{j}}^{\mathrm{I}}=-\frac{\sum_{\mathrm{i} \in \alpha \mathrm{G}}\left|\mathrm{F}_{\mathrm{ji}}\right|\left|\mathrm{V}_{\mathrm{i}}\right| \sin \mid \theta_{\mathrm{ji}}+\delta_{\mathrm{i}}-\delta_{\mathrm{j}}}{\left|\mathrm{V}_{\mathrm{j}}\right|}
$$

The voltage stability indicator at each bus is a function of voltage angles and magnitudes. The real and imaginary parts of indicators can be expressed as:

$$
\begin{aligned}
& \mathrm{L}^{\mathrm{I}}=\mathrm{F}_{1} d(\delta,|\mathrm{V}|) \\
& \mathrm{L}^{\mathrm{R}}=\mathrm{F}_{2}(\delta,|\mathrm{V}|)
\end{aligned}
$$

The partial derivative of Equations (33) \& (34) with respect to voltage angle and magnitude changes can be determined as

$$
\left[\begin{array}{l}
\Delta \mathrm{L}^{\mathrm{I}} \\
\Delta^{\mathrm{R}}
\end{array}\right]=\left[\begin{array}{l}
\frac{\partial \mathrm{L}^{\mathrm{I}}}{\partial \delta} \frac{\partial \mathrm{L}^{\mathrm{I}}}{\partial|\mathrm{V}|} \\
\frac{\partial \mathrm{L}^{\mathrm{R}}}{\partial \delta} \frac{\partial \mathrm{L}^{\mathrm{R}}}{\partial|\mathrm{V}|}
\end{array}\right]\left[\begin{array}{l}
\Delta \delta \\
\Delta \mid \mathrm{V}
\end{array}\right]=[\mathrm{T}]\left[\begin{array}{l}
\Delta \delta \\
\Delta|\mathrm{V}\rangle
\end{array}\right]
$$

Matrix [T] is the sensitivity matrix between indicator changes and voltage angle and magnitude changes

Coefficient of matrix [T] can be determined as

$$
\frac{\partial \mathrm{L}_{\mathrm{J}}^{\mathrm{I}}}{\partial \delta \mathrm{i}}=-\frac{\left|\mathrm{F}_{\mathrm{ji}}\right|\left|\mathrm{V}_{\mathrm{i}}\right| \cos \left(\theta_{\mathrm{ji}}+\delta_{\mathrm{i}}-\delta_{\mathrm{j}}\right)}{\left|\mathrm{V}_{\mathrm{j}}\right|} \mathrm{i} \in \alpha \mathrm{G}, \mathrm{i} \neq s
$$

( $\mathrm{S}$ indicates the swing bus)

$$
\begin{aligned}
& \frac{\partial \mathrm{L}_{\mathrm{j}}^{\mathrm{I}}}{\partial \delta \mathrm{j}}=\frac{\sum_{\mathrm{i} \in \alpha \mathrm{G}}\left|\mathrm{F}_{\mathrm{ji}}\right|\left|\mathrm{V}_{\mathrm{i}}\right| \cos \left(\theta_{\mathrm{ji}}+\delta_{\mathrm{i}}-\delta_{\mathrm{j}}\right)}{\left|\mathrm{V}_{\mathrm{j}}\right|}=\left(\mathrm{L}_{\mathrm{j}}^{\mathrm{R}}-1\right) \\
& \frac{\partial \mathrm{L}_{\mathrm{j}}^{\mathrm{R}}}{\partial \delta_{\mathrm{i}}}=\frac{\left|\mathrm{F}_{\mathrm{ji}}\right|\left|\mathrm{V}_{\mathrm{i}}\right| \sin \left(\theta_{\mathrm{ji}}+\delta_{\mathrm{i}}-\delta_{\mathrm{j}}\right)}{\left|\mathrm{V}_{\mathrm{j}}\right|} \\
& \frac{\partial \mathrm{L}_{\mathrm{j}}^{\mathrm{R}}}{\partial \delta_{\mathrm{i}}}=-\frac{\sum_{\mathrm{i} \in \alpha \mathrm{G}}\left|\mathrm{F}_{\mathrm{ji}}\right|\left|\mathrm{V}_{\mathrm{i}}\right| \sin \left(\theta_{\mathrm{ji}}+\delta_{\mathrm{i}}-\delta_{\mathrm{j}}\right)}{\left|\mathrm{V}_{\mathrm{j}}\right|}=\mathrm{L}_{\mathrm{j}}^{\mathrm{I}} \\
& \frac{\partial L_{j}^{I}}{\partial\left|V_{j}\right|}=\frac{\sum_{i \in O G}\left|F_{j i}\right|\left|V_{i}\right| \sin \left(\theta_{j i}+\delta_{i}-\delta_{j}\right)}{\left|V_{j}\right|^{2}}=\frac{L_{j}^{I}}{\left|V_{j}\right|} \\
& \frac{\partial_{j}^{\mathrm{R}}}{\partial \mathrm{V}_{\mathrm{j}} \mid}=\frac{\sum_{\mathrm{i} \in \mathrm{G}}\left|\mathrm{F}_{\mathrm{ji}}\right|\left|\mathrm{V}_{\mathrm{i}}\right| \cos \left(\theta_{\mathrm{ji}}+\delta_{\mathrm{i}}-\delta_{\mathrm{j}}\right)}{\left|\mathrm{V}_{\mathrm{j}}\right|^{2}}=\frac{\mathrm{L}_{\mathrm{j}}^{\mathrm{R}}-1}{\left|\mathrm{~V}_{\mathrm{j}}\right|}
\end{aligned}
$$

Form conventional Newton-Raphson Load flow we obtain a linear relation between changes in voltage phase/magnitudes and active/reactive power injections as:

$$
\left[\begin{array}{l}
\Delta \delta \\
\Delta|\mathrm{V}|
\end{array}\right]=[\mathrm{j}]^{-1}\left[\begin{array}{l}
\Delta \mathrm{P} \\
\Delta \mathrm{Q}
\end{array}\right]
$$

Sub (44) in (37) we get a relationship between real and imaginary parts of indicators and injected power as:

$$
\left[\begin{array}{c}
\Delta \mathrm{L}^{\mathrm{I}} \\
\Delta \mathrm{L}^{\mathrm{R}}
\end{array}\right]=[\mathrm{T}][\mathrm{j}]^{-1}\left[\begin{array}{c}
\Delta \mathrm{P} \\
\Delta \mathrm{Q}
\end{array}\right]
$$

A relationship between changes in indicators at load bus $\mathrm{j}$ and power injections at all load buses can be obtained:

$$
\begin{aligned}
& \Delta \mathrm{L}_{\mathrm{j}}^{\mathrm{I}}=\mathrm{S}_{11} \Delta \mathrm{P}_{\mathrm{j}}+\mathrm{S}_{12} \Delta \mathrm{Q}_{\mathrm{j}} \\
& \Delta \mathrm{L}_{\mathrm{j}}^{\mathrm{R}}=\mathrm{S}_{21} \Delta \mathrm{P}_{\mathrm{j}}+\mathrm{S}_{22} \Delta \mathrm{Q}_{\mathrm{j}}
\end{aligned}
$$

The active and reactive loads are not independent: one cannot shed active loads without reducing reactive loads. Usually a relation between active and reactive load can be obtained as follows. Here the load power factor is assumed to be constant at each load bus.

$$
\begin{gathered}
P f_{j}=\frac{Q_{j}}{P_{j}} \quad j \in \alpha_{L} \\
P f_{j}=\frac{\Delta Q_{j}}{\Delta P_{j}} \\
\Delta Q_{j}=P f_{j} \Delta P_{j}
\end{gathered}
$$

Sub (48) in (46and47) we get a relationship between changes of the indicator at bus $j$ and changes in active power injected at the same bus can be obtained as

$$
\begin{gathered}
\Delta \mathrm{L}_{\mathrm{j}}^{\mathrm{I}}=\mathrm{S}_{11} \Delta \mathrm{P}_{\mathrm{j}}+\mathrm{S}_{12} \mathrm{Pf}_{\mathrm{j}} \Delta \mathrm{P}_{\mathrm{j}} \\
\Delta \mathrm{L}_{\mathrm{j}}^{\mathrm{R}}=\mathrm{S}_{21} \Delta \mathrm{P}_{\mathrm{j}}+\mathrm{S}_{22} \mathrm{Pf}_{\mathrm{j}} \Delta \mathrm{P}_{\mathrm{j}} \\
\Delta \mathrm{L}_{\mathrm{j}}^{\mathrm{I}}=\mathrm{S}_{1} \Delta \mathrm{P}_{\mathrm{j}} \\
\Delta \mathrm{L}_{\mathrm{j}}^{\mathrm{R}}=\mathrm{S}_{2} \Delta \mathrm{P}_{\mathrm{j}}
\end{gathered}
$$

where

$$
\begin{gathered}
\mathrm{S}_{1}=\mathrm{S}_{11}+\mathrm{S}_{12} \mathrm{Pf}_{\mathrm{j}} \\
\mathrm{S}_{2}=\mathrm{S}_{21}+\mathrm{S}_{22} \mathrm{Pf}_{\mathrm{j}} \\
\Delta \mathrm{L}_{\mathrm{j}}=\sqrt{\left(\Delta \mathrm{L}_{\mathrm{j}}^{\mathrm{I}}\right)^{2}+\left(\Delta \mathrm{L}_{\mathrm{j}}^{\mathrm{R}}\right)^{2}} \\
\Delta \mathrm{L}_{\mathrm{j}}=\sqrt{\mathrm{S}_{1}{ }^{2} \Delta \mathrm{P}_{\mathrm{j}}^{2}+\mathrm{S}_{2}{ }^{2} \Delta \mathrm{P}_{\mathrm{j}}^{2}} \\
\Delta \mathrm{L}_{\mathrm{j}}=\sqrt{\left(\mathrm{S}_{1}{ }^{2}+\mathrm{S}_{2}{ }^{2}\right) \Delta \mathrm{P}_{\mathrm{j}}^{2}} \\
\Delta \mathrm{L}_{\mathrm{j}}=\Delta \mathrm{P}_{\mathrm{j}} \sqrt{\left(\mathrm{S}_{1}{ }^{2}+\mathrm{S}_{2}{ }^{2}\right)}
\end{gathered}
$$




$$
\begin{gathered}
\Delta \mathrm{P}_{\mathrm{j}}=\frac{\Delta \mathrm{L}_{\mathrm{j}}}{\sqrt{\left(\mathrm{S}_{1}^{2}+\mathrm{S}_{2}^{2}\right)}} \\
\Delta \mathrm{Q}_{\mathrm{j}}=\mathrm{Pf}_{\mathrm{j}} \Delta \mathrm{P}_{\mathrm{j}}
\end{gathered}
$$

Using Equation (57) reactive power to be shed at bus $\mathrm{j}$ can be obtained if the active power to be shed at bus $\mathrm{j}$ is know.

\section{Algorithm for Calculation Load to Be Shed}

The step by step procedure of load shedding algorithm is given as follows

Step 1

Carry out load flow by Newton Raphson Method.

\section{Step 2}

Calculate voltage stability indicator for all load buses and find Lmax.

\section{Step 3}

Check Lmax $\geq$ Lcritical, if exceeds we have to shed a part of load at that bus with

maximum value of L, goto next step. Else there is no need to shed the load stop.

\section{Step 4}

Using Equations (56 and 57), calculate the required load to be shed.

\section{Step 5}

Remove this load and goto step (1)

i.e. (subtract this $\Delta P_{j}$ and $\Delta Q_{j}$ from the $j^{\text {th }}$ load bus).

\section{Numerical Examples, Simulation Results and Analysis}

The study has been conducted on test cases with standard 6 bus Ward-Hale test system and IEEE-14 bus test system. The voltage stability indicator for all load buses are computed by two methods for various load patterns and results are tabulated.

To verify the feasibility of the improved method, two different power systems were tested, under various base cases. The solutions were compared by their solution quality and computation efficiency. From the experiences of many experiments the optimum load shedding algorithms have been used to solve the above test cases and are results are tabulated. For implementing the above algorithm, the simulation studies were carried out on P-IV, $2.4 \mathrm{GHz}, 512$ MBDDR RAM systems in MAT$\mathrm{LAB}$ environment. The load shedding results for the first test case with the corresponding base cases are tabulated in Tables 1-6.

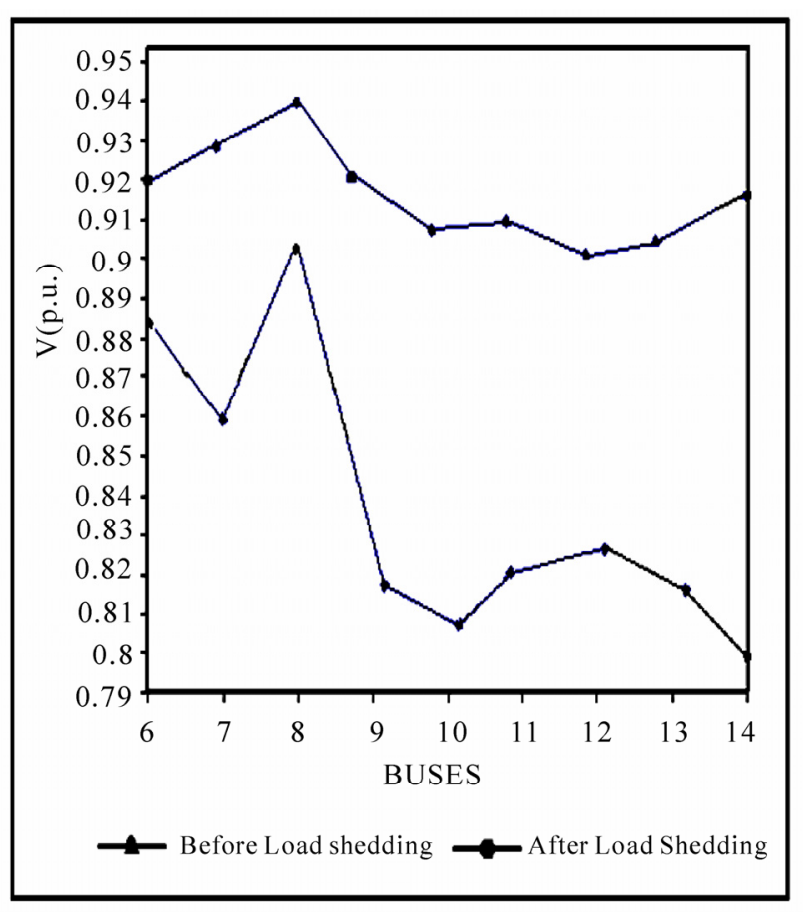

Figure 1. Voltage profile for standard 6 bus ward-hale test system.

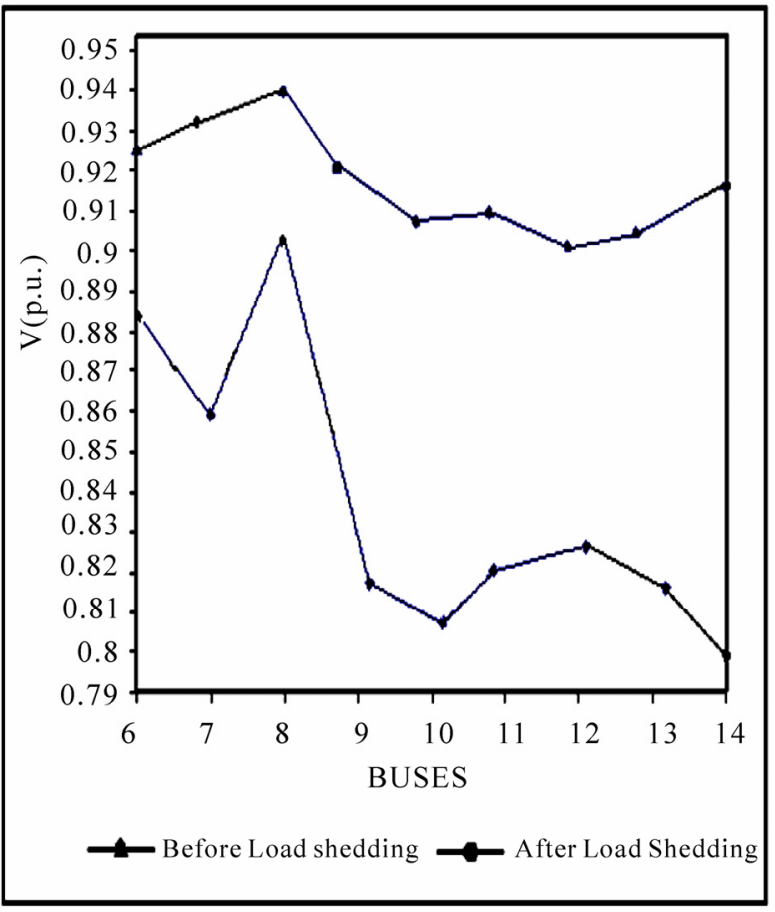

Figure 2. Voltage profile for IEEE-14 bus test system.

Table 1 illustrates the results of load flow solution of 1.5 times the base power; the maximum value of the $\mathrm{B}$ indicator is 0.572051 at bus 5 . Therefore it is the bus at which load must be shed. Using the proposed method, 
the quantity of load to be shed is found and shown in the same table. The B indicator after shedding and the bus voltage magnitude after each load shed is given in the same Table 1.

In case study I using method 1 the maximum value of indicators occur at bus 3,5 and 6. Using the improved method the impact of maximum value of indicators occurred at bus 3, 5 and 6 got reduced and illustrated in Table 2 .

The successive load shedding and improvement in voltage magnitude with the maximum value of $B$ indicator less than the B critical value for load flow solution 1.1 times and 1.0 times the base power is illustrated for both the methods were illustrated in Tables 3,4,5 and 6 for 6 bus Ward-Hale test system.

The results from the improved method is compared with the method proposed by T. Quoc Taun et al. [4-5] in Tables 7,8,9,10,11, and 12 for IEEE-14 bus system for different loading conditions respectively. Analysis of these tables shows that shedding of selected loads at selected buses improves the voltage magnitude at all buses. In addition, the stability of the system is improved.

The computation time of these two methods for different loading conditions are tabulated in Tables 13 and 14. From these tables, it is very clear that the computation time of the proposed method is slightly higher than method-I . The various results obtained by the two methods show that both the methods are quite effective. But, in the proposed method both resistance and reactance are taken into account hence this method is more accurate and yields more computation time. Figure 1 and Figure 2 show the improved voltage profile of the proposed algorithm for standard 6 bus ward-hale test system and IEEE-14 bus test system The figure shows that the algorithm is capable of obtaining a faster convergence for the three unit thermal system in a very few generations and the solution is consistent.

\section{Test case 1: 6 bus ward-hale test system}

Case study i

Method -i

Table 1. Load flow solution 1.5 times the base power.

\begin{tabular}{ccccc}
\hline $\begin{array}{c}\text { Bus } \\
\text { number }\end{array}$ & $\begin{array}{c}\text { Bus voltage } \\
\text { magnitude } \\
\text { (before load } \\
\text { shedding) }\end{array}$ & $\begin{array}{c}\text { B indicator } \\
\text { (before load } \\
\text { shedding) }\end{array}$ & $\begin{array}{c}\text { Sheddable load } \\
\text { B indicator } \\
\text { (after load } \\
\text { shedding) }\end{array}$ & $\begin{array}{c}\text { Bus voltage } \\
\text { magnitude(after load } \\
\text { shedding) }\end{array}$ \\
\hline 3 & 0.792526 & 0.552319 & $-0.278049-\mathrm{j} 0.065721$ & 0.299996 \\
4 & 0.821274 & 0.421552 & 0.00 & 0.230428 \\
5 & 0.761915 & 0.572051 & $-0.196304-\mathrm{j} 0.117783$ & 0.907653 \\
6 & 0.788985 & 0.535638 & $-0.123482-\mathrm{j} 0.012348$ & 0.299993 \\
\hline
\end{tabular}

Alpha: 1.5 Bcri: 0.3

Method -II

Table 2. Load flow solution 1.5 times the base power.

\begin{tabular}{ccccc}
\hline $\begin{array}{c}\text { Bus } \\
\text { number }\end{array}$ & $\begin{array}{c}\text { Bus voltage } \\
\text { magnitude } \\
\text { (before load } \\
\text { shedding) }\end{array}$ & $\begin{array}{c}\text { B indicator } \\
\text { (before load } \\
\text { shedding) }\end{array}$ & $\begin{array}{c}\text { Sheddable load } \\
\text { Bus voltage }\end{array}$ & $\begin{array}{c}\text { indicator } \\
\text { (after load shedding) } \\
\text { magnitude(after load } \\
\text { shedding) }\end{array}$ \\
\hline 3 & 0.792526 & 0.565819 & $-0.272274-\mathrm{j} 0.064356$ & 0.299995 \\
4 & 0.821274 & 0.427228 & 0.00 & 0.230818 \\
5 & 0.761915 & 0.589754 & $-0.190293-\mathrm{j} 0.114176$ & 0.299906 \\
6 & 0.788985 & 0.537283 & $-0.121310-\mathrm{j} 0.012131$ & 0.931995 \\
\hline
\end{tabular}

Alpha: 1.5 Bcri: 0.3

Case Study 2

Method I

Table 3. Load flow solution 1.1 times the base power.

\begin{tabular}{ccccc}
\hline $\begin{array}{c}\text { Bus } \\
\text { number }\end{array}$ & $\begin{array}{c}\text { Bus voltage magni- } \\
\text { tude } \\
\text { (before load shed- } \\
\text { ding) }\end{array}$ & $\begin{array}{c}\text { B indicator } \\
\text { (before } \\
\text { load shedding) }\end{array}$ & $\begin{array}{c}\text { Sheddable load } \\
\text { B indicator } \\
\text { (after load shed- } \\
\text { ding) }\end{array}$ & $\begin{array}{c}\text { Bus voltage magnitude } \\
\text { (after load shedding) }\end{array}$ \\
\hline 3 & 0.910748 & 0.309107 & $-0.013415-\mathrm{j} 0.003171$ & 0.299995 \\
5 & 0.929561 & 0.239028 & 0.00 & 0.231807 \\
6 & 0.891220 & 0.312879 & $-0.019480-\mathrm{j} 0.011688$ & 0.298756 \\
\hline
\end{tabular}

Alpha: 1.1 Bcri: 0.3 


\section{Method II}

Table 4. Load flow solution 1.1 times the base power.

\begin{tabular}{ccccc}
\hline $\begin{array}{c}\text { Bus } \\
\text { number }\end{array}$ & $\begin{array}{c}\text { Bus voltage } \\
\text { magnitude } \\
\text { (before load } \\
\text { shedding) }\end{array}$ & $\begin{array}{c}\text { B indicator } \\
\text { (before load shed- } \\
\text { ding) }\end{array}$ & $\begin{array}{c}\text { Sheddable load } \\
\text { B indicator } \\
\text { (after load } \\
\text { shedding) }\end{array}$ & $\begin{array}{c}\text { Bus voltage } \\
\text { magnitude(after } \\
\text { load shedding) }\end{array}$ \\
\hline 3 & 0.910748 & 0.313655 & $-0.019744-\mathrm{j} 0.004430$ & 0.299995 \\
4 & 0.929561 & 0.240298 & 0.00 & 0.229818 \\
6 & 0.891220 & 0.318878 & $-0.026911-\mathrm{j} 0.016146$ & 0.298020 \\
6 & 0.911773 & 0.295298 & 0.00 & 0.936187 \\
\hline
\end{tabular}

Alpha: 1.1 Bcri: 0.3

Case Study 3

Method I

Table 5. Load flow solution 1.0 times the base power.

\begin{tabular}{ccccc}
\hline $\begin{array}{c}\text { Bus } \\
\text { number }\end{array}$ & $\begin{array}{c}\text { Bus voltage } \\
\text { magnitude } \\
\text { (before load } \\
\text { shedding) }\end{array}$ & $\begin{array}{c}\text { B indicator } \\
\text { (before load } \\
\text { shedding) }\end{array}$ & $\begin{array}{c}\text { Sheddable load } \\
\text { B indicator } \\
\text { (after load } \\
\text { shedding) }\end{array}$ & $\begin{array}{c}\text { Bus voltage } \\
\text { magnitude(after } \\
\text { load shedding) }\end{array}$ \\
\hline 3 & 0.931663 & 0.268746 & 0.00 & - \\
5 & 0.948248 & 0.208422 & 0.00 & - \\
6 & 0.914858 & 0.270784 & 0.00 & - \\
\hline
\end{tabular}

Alpha: 1.0 Bcri: 0.3

\section{Method II}

Table 6. Load flow solution 1.0 times the base power.

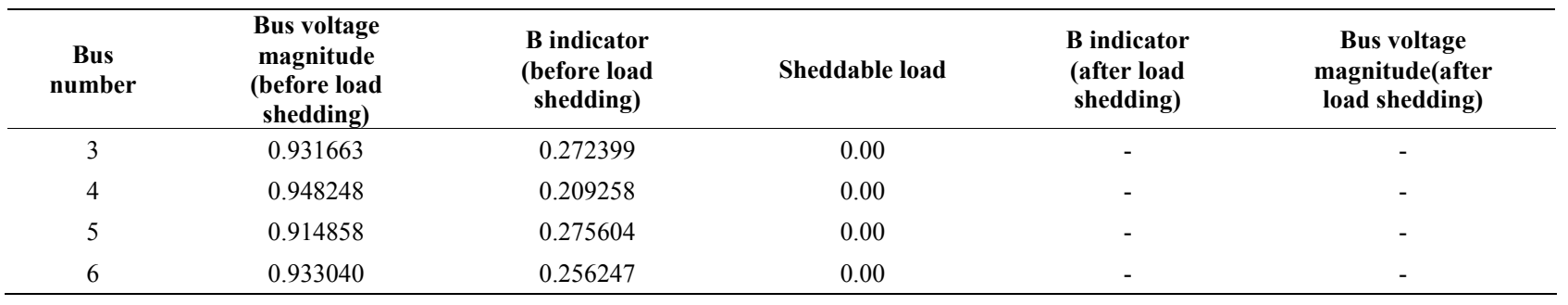

Alpha: 1.0 Bcri: 0.3

Test Case 2: IEEE 14 Bus System

Case Study 1

Method I

Table 7. Load flow solution 1.75 times the base power.

\begin{tabular}{|c|c|c|c|c|c|}
\hline Bus number & $\begin{array}{c}\text { Bus voltage } \\
\text { magnitude } \\
\text { (before load } \\
\text { shedding) }\end{array}$ & $\begin{array}{c}\text { B indicator } \\
\text { (before load shedding) }\end{array}$ & Sheddable load & $\begin{array}{c}\text { B indicator } \\
\text { (after load shedding) }\end{array}$ & $\begin{array}{c}\text { Bus voltage } \\
\text { magnitude } \\
\text { (after load shedding) }\end{array}$ \\
\hline 6 & 0.885987 & 0.076577 & 0.00 & 0.065605 & 0.926245 \\
\hline 7 & 0.861489 & 0.103337 & 0.00 & 0.068974 & 0.935048 \\
\hline 8 & 0.903179 & 0.052732 & 0.00 & 0.045991 & 0.939599 \\
\hline 9 & 0.826483 & 0.188466 & $-0.117981-\mathrm{j} 0.066389$ & 0.116584 & 0.915637 \\
\hline 11 & 0.835082 & 0.101553 & 0.00 & 0.068160 & 0.912634 \\
\hline 12 & 0.832003 & 0.065987 & 0.00 & 0.046524 & 0.909214 \\
\hline 13 & 0.825003 & 0.090781 & 0.00 & 0.056859 & 0.906149 \\
\hline 14 & 0.797535 & 0.225521 & $-0.22901-\mathrm{j} 0.076913$ & 0.100380 & 0.910447 \\
\hline
\end{tabular}

Alpha: 1.75 Bcri : 0.12 
Method II

Table 8. Load flow solution 1.75 times the base power.

\begin{tabular}{cccccc}
\hline Bus number & $\begin{array}{c}\text { Bus voltage } \\
\text { magnitude } \\
\text { (before load shedding) }\end{array}$ & $\begin{array}{c}\text { B indicator } \\
\text { (before load shedding) }\end{array}$ & Sheddable load & $\begin{array}{c}\text { B indicator } \\
\text { (after load shed- } \\
\text { ding) }\end{array}$ & $\begin{array}{c}\text { Bus voltage } \\
\text { magnitude } \\
\text { (after load shedding) }\end{array}$ \\
\hline 6 & 0.885987 & 0.071513 & 0.00 & 0.060637 & 0.919887 \\
7 & 0.861489 & 0.101100 & 0.00 & 0.068528 & 0.923378 \\
8 & 0.903179 & 0.048410 & 0.00 & 0.041661 & 0.933292 \\
9 & 0.826483 & 0.187316 & $-0.112015-\mathrm{j} 0.063032$ & 0.119214 & 0.901171 \\
10 & 0.817095 & 0.18039 & $-0.001460-\mathrm{j} 0.000094$ & 0.119999 & 0.888367 \\
11 & 0.835082 & 0.101179 & 1 & 0.070317 & 0.894098 \\
12 & 0.832003 & 0.067257 & 0.00 & 0.049879 & 0.887929 \\
13 & 0.825003 & 0.090801 & 0.00 & 0.059871 & 0.885136 \\
14 & 0.797535 & 0.225110 & $-0.220811-\mathrm{j} 0.074098$ & 0.105331 & 0.892381 \\
\hline
\end{tabular}

Alpha : 1.75 Lcri : 0.12

\section{Case study II}

Method I

Table 9. Load flow solution 1.5 times the base power.

\begin{tabular}{cccccc}
\hline Bus number & $\begin{array}{c}\text { Bus voltage } \\
\text { magnitude } \\
\text { (before load shedding) }\end{array}$ & $\begin{array}{c}\text { B indicator } \\
\text { (before load shedding) }\end{array}$ & Sheddable load & $\begin{array}{c}\text { B indicator } \\
\text { (after load shed- } \\
\text { ding) }\end{array}$ & $\begin{array}{c}\text { Bus voltage magni- } \\
\text { tude } \\
\text { (after load shed- } \\
\text { ding) }\end{array}$ \\
\hline 6 & 0.965883 & 0.056862 & 0.00 & 0.054954 & 0.968854 \\
7 & 0.961972 & 0.071512 & 0.00 & 0.066872 & 0.965849 \\
8 & 0.975622 & 0.039895 & 0.00 & 0.038464 & 0.978367 \\
9 & 0.939840 & 0.126675 & 0.00 & 0117218 & 0.946047 \\
10 & 0.932435 & 0.121099 & 0.00 & 0.113175 & 0.937631 \\
11 & 0.944580 & 0.068419 & 0.00 & 0.064546 & 0.947266 \\
12 & 0.944571 & 0.044103 & 0.00 & 0.041059 & 0.946053 \\
13 & 0.937257 & 0.060500 & 0.00 & 0.054197 & 0.940925 \\
14 & 0.918004 & 0.148539 & $-0.092214-\mathrm{j} 0.030944$ & 0.119998 & 0.932353 \\
\hline
\end{tabular}

Alpha : 1.5 Bcri : 0.12

\section{Method II}

Table 10. Load flow solution 1.5 times the base power.

\begin{tabular}{|c|c|c|c|c|c|}
\hline $\begin{array}{c}\text { Bus } \\
\text { number }\end{array}$ & $\begin{array}{l}\text { Bus voltage magnitude } \\
\text { ( before load shedding) }\end{array}$ & $\begin{array}{l}\text { B indicator } \\
\text { (before load } \\
\text { shedding) }\end{array}$ & Sheddable load & $\begin{array}{c}\text { B indicator } \\
\text { (after load } \\
\text { shedding) }\end{array}$ & $\begin{array}{c}\text { Bus voltage magni- } \\
\text { tude } \\
\text { (after load shed- } \\
\text { ding) }\end{array}$ \\
\hline 7 & 0.961972 & 0.069175 & 0.00 & 0.064798 & 0.965592 \\
\hline 8 & 0.975622 & 0.035267 & 0.00 & 0.034432 & 0.978183 \\
\hline 9 & 0.939840 & 0.124902 & 0.00 & 0.115731 & 0.945636 \\
\hline 10 & 0.932435 & 0.119784 & 0.00 & 0.112075 & 0.937287 \\
\hline 11 & 0.944580 & 0.067704 & 0.00 & 0.063903 & 0.947088 \\
\hline 12 & 0.944571 & 0.044896 & 0.00 & 0.041999 & 0.945956 \\
\hline 13 & 0.937257 & 0.060239 & 0.00 & 0.054229 & 0.940652 \\
\hline 14 & 0.918004 & 0.147165 & $-0.085875-\mathrm{j} 0.028817$ & 0.119997 & 0.931398 \\
\hline
\end{tabular}

Alpha : 1.5 Lcri : 0.12 
Case Study III

Method I

Table 11. Load flow solution 1.25 times the base power.

\begin{tabular}{ccccc}
\hline $\begin{array}{c}\text { Bus } \\
\text { number }\end{array}$ & $\begin{array}{c}\text { Bus voltage } \\
\text { Magnitude } \\
\text { (before load shedding) }\end{array}$ & $\begin{array}{c}\text { B indicator } \\
\text { (before load shedding) }\end{array}$ & $\begin{array}{c}\text { Sheddable load } \\
\text { (after load shedding) }\end{array}$ & $\begin{array}{c}\text { Bus voltage } \\
\text { magnitude } \\
\text { (after load shedding) }\end{array}$ \\
\hline 6 & 0.991775 & 0.045028 & 0.00 & - \\
7 & 0.984258 & 0.056165 & 0.00 & - \\
8 & 1.000579 & 0.031853 & 0.00 & - \\
9 & 0.972796 & 0.098070 & 0.00 & - \\
10 & 0.967549 & 0.093527 & 0.00 & - \\
11 & 0.978900 & 0.052892 & 0.00 & - \\
12 & 0.980368 & 0.034090 & 0.00 & - \\
13 & 0.974269 & 0046519 & 0.00 & - \\
14 & 0.956955 & 0.113685 & 0.00 & - \\
\hline
\end{tabular}

Alpha : 1.25 Bcri : 0.1

\section{Method II}

Table 12. Load flow solution 1.25 times the base power.

\begin{tabular}{|c|c|c|c|c|c|}
\hline $\begin{array}{c}\text { Bus } \\
\text { number }\end{array}$ & $\begin{array}{c}\text { Bus voltage } \\
\text { Magnitude } \\
\text { (before load shedding) } \\
\end{array}$ & $\begin{array}{c}\text { B indicator } \\
\text { (before load shedding) }\end{array}$ & Sheddable load & $\begin{array}{c}\text { B indicator } \\
\text { (after load shedding) }\end{array}$ & $\begin{array}{c}\text { Bus voltage } \\
\text { magnitude } \\
\text { (after load shedding) }\end{array}$ \\
\hline 6 & 0.991775 & 0.040850 & 0.00 & - & - \\
\hline 7 & 0.984258 & 0.054596 & 0.00 & - & - \\
\hline 8 & 1.000579 & 0.027980 & 0.00 & - & - \\
\hline 9 & 0.972796 & 0.097214 & 0.00 & - & - \\
\hline 11 & 0.978900 & 0.052608 & 0.00 & - & - \\
\hline 12 & 0.980368 & 0.034715 & 0.00 & - & - \\
\hline 13 & 0.974269 & 0.046498 & 0.00 & - & - \\
\hline 14 & 0.956955 & 0.113325 & 0.00 & - & - \\
\hline
\end{tabular}

Alpha : 1.25 Lcri : 0.12

Table 13. Computation time in sec for 6 bus Ward-Hale test system.

\begin{tabular}{ccc}
\hline Cases & & Computation time (secs.) \\
\cline { 2 - 3 } & Method I & Method II \\
\hline Case 1 & 0.66 & 0.82 \\
Case 3 & 0.61 & 0.66 \\
0.27 & 0.22 & 0.27 \\
\hline
\end{tabular}

Table 14. Computation time in sec for IEEE-14 bus system.

\begin{tabular}{lccr}
\hline Cases & & Computation time (secs.) \\
\cline { 2 - 3 } & Method I & Method II \\
\hline Case 1 & 1.21 & 1.42 \\
Case 2 & 0.88 & 1.15 \\
Case 3 & 0.49 & 0.55 \\
\hline
\end{tabular}

\section{Conclusions}

A simple new method is developed to determine the optimum location and the optimum quantity of load to be shed in order to prevent the system voltage from going to the unstable. This method is based on indicators of risk of voltage instability. It can be implemented for large power system to estimate voltage instability. Successive load flow runs are required to accomplish this method. The proposed method can be used for real time applications in power systems. The computation speed of these indicators is fast compared to other methods.

\section{Acknowledgment}

The authors gratefully acknowledge the the Management 
of Pondicherry Engineering College, Pondicherry, INDIA for their continued support, encouragement and the facilities provided to carry out this research work.

\section{References}

[1] C. W. Taylor, "Concept of under voltage load shedding for voltage stability," IEEE transactions on Power Delivery, Vol. 7, No. 2, pp. 480-488, 1992

[2] S. A. Niern berg, D. A. Meinnis, and K. D. Sparks, "Fast acting load shedding," IEEE Transactions on Power Systems, Vol. 7, No. 2, pp. 873-877, 1992.

[3] P. Kessel and H. Glavitsch, "Estimating the voltage stability of a power system," IEEE Transactions on Power Delivery, Vol. 1, No. 3, pp. 346-354, 1986,

[4] T. Quoc Taun, J. Fandino, N. Hadjsaid, and J. C. sabonnadiere, $\mathrm{H}$. $\mathrm{Vu}$, "Emergency load shedding to avoid risks of voltage instability using indicators," IEEE Transactions on Power Systems, Vol. 9, No. 1, pp. 341-351, 1994.

[5] T. Quoc Taun, J. Fandino, N. Hadjsaid, and J. C. sabonnadiere, "Fast calculation of indicators of risk of voltage instability," Proc .of $27^{\text {th }}$ Universities Power Engineering Conference, UPEC-92, pp. 612-615, 1992.

[6] C. W. Taylor, "Power system voltage stability," Mc.Graw Hill, 1993.

[7] L. P. Hajdu, J. Peschon, W. F. Tinney, and D. S. Piercy, "Optimum load-shedding policy for power system," IEEE Tran, PAS-87, No. 3, pp. 784-794, 1968.

[8] D. K. Subramanian, "Optimum load shedding through programming techniques," IEEE Trans, PAS-90, pp. 89-94, 1971.

[9] S. M. Chan and F. C. Schweppe, "A generation rellocation and load shedding algorithm," IEEE Trans., PAS-98, No. 1, pp. 26-34, 1979.

[10] M. M. Adibi and D. K. Thorne, "Local load shedding,"
IEEE Trans. On Power System, Vol. 3, No. 3, pp. 1220-1226, 1988.

[11] S. Shah and S. M. Shahldehpour, "A heuristic approach to load shedding scheme," IEEE Trans, on Power System, Vol. 4, No. 4, pp. 1421-1429, 1989.

[12] R. Billinton and J. Satish, "Effect of rotational load shedding on overall power system adequacy indices," IEE Proc. C, Vol. 143, No. 2, pp. 181-187, 1996.

[13] P. Wang and R. Billinton, "Optimum load-shedding technique to reduce the total customer interruption cost in a distribution system," IEE Proc. - Gener. Transm. Distrib., Vol. 147, No. 1, pp. 51-56, 2000.

[14] D. Xu and A. A. Girgis, "Optimal Load Shedding Strategy in Power Systems with Distributed Generation," IEEE, pp. 788-793, 2001.

[15] Y. Lu, W. S. Kao, and Y. T. Chen, "Study of applying load shedding scheme with dynamic d-factor values of various dynamic load models to taiwan power system," IEEE Transactions on Power Systems, Vol. 20, No. 4, pp. 1976-1984, 2005.

[16] R. Faranda, A. Pievatolo, and E. Tironi, "Load shedding: A new proposal," IEEE Transactions on Power Systems, Vol. 22, No. 4, pp. 2086-2093, 2007.

[17] A. Wiszniewski, "New criteria of voltage stability margin for the purpose of load shedding," IEEE Transactions on Power Delivery, Vol. 22, No. 3, pp. 1367-1371, 2007.

[18] Z. P. Ding, S. K. Srivastava, D. A. Cartes, and S. Suryanarayanan, "Dynamic simulation-based analysis of a new load shedding scheme for a notional destroyer-class shipboard power system," IEEE Transactions on Industry Applications, Vol. 45, No. 3, pp. 1163-1174, 2009.

[19] E. J. Thalassinakis, E. N. Dialynas, and D. Agoris, "Method combining anns and monte carlo simulation for the selection of the load shedding protection strategies in autonomous power systems," IEEE Transactions on Power Systems, Vol. 21, No. 4, pp. 1574-1582. 2006. 